\title{
The use of Moodle platform in the traditional transition of Information Technology Science in medicine to foreign students accepted on the basis of MBBS program at Bukhara State Medical Institute
}

\section{Yulduz ASADOVA ${ }^{1}$ \\ Bukhara State Medical Institute}

\begin{tabular}{l} 
ARTICLE INFO \\
\hline Article history: \\
Received June 2021 \\
Received in revised form \\
20 June 2021 \\
Accepted 15 July 2021 \\
Available online \\
15 August 2021
\end{tabular}

Keywords:

course management system, moodle,

e-learning,

higher education,

homework.

\begin{abstract}
Web-adapted collaborative learning environments are often used to support individual learning activities. This article describes how Pakistani and Indian students can improve the quality of their educational process and increase the students' ability to perform assigned tasks and other work, attend classes at higher educational institutions within the framework of the MBBS program for foreign students entering medical institute. We describe the implementation and use of e-learning platforms and present our experience of using such platforms on the example of our faculty. We analyze the scientific activities of students who also use the e-learning platform, where they can get access to course resources and homework. In addition, they must submit their homework through the platform, meet strict deadlines and use feedback from teachers to improve the quality of their homework. This article presents the results of a scientific study on the use of the Moodle electronic platform when passing traditional training in the system of full-time method of education.
\end{abstract}

2181-1415/C) 2021 in Science LLC.

This is an open access article under the Attribution 4.0 International (CC BY 4.0) license (https://creativecommons.org/licenses/by/4.0/deed.ru)

\footnotetext{
${ }^{1}$ Assistant, Bukhara State Medical Institute, Bukhara, Uzbekistan.

E-mail: sirus77@inbox.ru.
} 


\section{Buxoro davlat tibbiyot institutida Tibbiyotda axborot texnologiyalari fanini MBBS dasturi asosida qabul qilingan xorijlik talabalarga an'anaviy o'tishda Moodle platformasidan foydalanish}

Kalit so'zlar:

kurslarni boshqarish tizimi, moodle,

elektron ta'lim, oliy ma'lumot, uy vazifasi.

\begin{abstract}
ANNOTATSIYA
Birgalikda ta'lim faoliyatini qo'llab-quvvatlash uchun Internetga asoslangan birgalikdagi o'quv muhitlari ishlatiladi. Ushbu maqolada qanday qilib pokistonlik va hindistonlik talabalar o'quv jarayonining sifatini oshirishi va talabalarning topshiriq va boshqa ishlarni bajarish qobiliyatini oshirishlari, MBBS dasturi bo'yicha tibbiyot fakultetiga kirayotgan xalqaro talabalar uchun oliy ma'lumot olishlari tasvirlangan. Biz elektron ta'lim platformalarini joriy etish va ulardan foydalanishni tasvirlaymiz va fakultetimiz misolida bunday platformalardan foydalanish tajribamizni taqdim etamiz. Biz o'quv resurslari va uy vazifalariga kira oladigan elektron o'quv platformasidan foydalanadigan talabalarning ilmiy faoliyatini tahlil qilamiz. Bundan tashqari, ular uy vazifalarini platforma orqali topshirishlari, qat'iy belgilangan muddatlarga rioya qilishlari va o'qituvchilarning fikr-mulohazalaridan foydalanib, uy ishlarining sifatini yaxshilashlari kerak. Ushbu maqola kunduzgi ta'lim tizimida an'anaviy treningdan o'tishda Moodle elektron platformasidan foydalanish bo'yicha o'tkazilgan ilmiy tadqiqot natijalarini taqdim etadi.
\end{abstract}

\section{Использование платформы Moodle при традиционном переходе на обучение иностранных студентов по программе MBBS в Бухарском государственном медицинском институте}

\footnotetext{
Ключевые слова:

система управления курсом,

moodle,

электронное обучение, высшее образование, домашнее задание.
}

\begin{abstract}
АННОТАЦИЯ
Веб-адаптированные среды совместного обучения часто используются для поддержки индивидуальной учебной деятельности. В этой статье описывается, как пакистанские и индийские студенты могут улучшить качество своего учебного процесса и увеличить способности студентов к выполнению возложенных заданий, а также другую работу, посещать занятия в высших учебных заведениях в рамках программы MBBS для иностранных студентов, поступающих в медицинский институт. Мы описываем внедрение и использование платформ электронного обучения и представляем наш опыт использования таких платформ на примере нашего факультета. Анализируется научная деятельность студентов, которые также используют платформу электронного обучения, где они могут получить
\end{abstract}




\begin{abstract}
доступ к курсовым ресурсам и домашним заданиям. Кроме того, они должны представить свои домашние задания через платформу, соблюдать строгие сроки и использовать обратную связь от преподавателей для улучшения качества своих домашних заданий. В данной статье предлагаются результаты научного исследования на предмет использования электронной платформы Moodle при прохождении традиционного обучения в системе очного метода образования.
\end{abstract}

\title{
INTRODUCTION
}

Modern education standards require the use of various tools to complement the teaching and learning processes, as well as effective assessment. The learning management system is often the basis of a reliable e-learning platform and meets the standards and best practices recommended by respectable educational and corporate stakeholders $[1,2]$.

At our departments of the Faculty of Natural Sciences of the University of Novi Sad in Serbia and the Faculty of Electrical Engineering and Computer Science of the University of Maribor in Slovenia, this solution is used to develop and conduct courses that support classroom learning [10].

A few years ago, we decided to use and possibly expand the existing e-learning platform for our e-courses instead of developing a new system that starts from scratch. After testing several systems, we made conclusions about the available tools. The system we chose was supposed to be one of the well-established general-purpose LMS solutions, preferably open source [8]. Such a platform, in addition to its flexibility and significant cost savings, would offer opportunities for expansion and customization according to specific needs $[3,4]$.

The open source LMS was evaluated according to a set of minimum criteria, which included an active community, a stable development status, good documentation, a didactic goal and a focus on content presentation and communication functions [1,7].

Our final choice was Moodle thanks to its excellent basic characteristics, great extensibility and even some potential adaptive features that have been further developed in Novi Sad [10]. A number of comparative studies and scientific papers [9, 23], we have confirmed our choice.

Moreover, this decision was adopted by the University of Maribor as an official LMS, and also introduced at a significant number of faculties in Novi Sad in the last couple of years, which certainly makes it more appropriate for joint study and reuse of educational material between our universities [10].

Moodle is a modular and extensible platform that offers features to support various educational styles. It basically follows established usability conventions. [1, 7]: it has a simple interface, uses a minimum number of words, has roll calls that provide additional information, etc. However, usability and privacy issues should be considered in detail when using such a solution.

\section{SURVEY PLAN AND METHODS}

At the Bukhara State Medical Institute, students were trained using the Moodle platform, one of the programs created to study online education along with traditional training in the field of information technologies in medicine. 
Today, when we live in the era of modern technologies, one of the most advanced learning technologies and modern internationally recognized applications is the Moodle platform, with which teachers can create their own training courses and use them to independently teach students through this course, as well as to improve their knowledge.From the subjects in this course, we give lectures, conduct practical classes, laboratory work, tests, etc.

At the Bukhara State Medical Institute, students are accepted according to three programs: groups of the national direction, students accepted according to joint programs, and students accepted according to the MBBS program.

The process of teaching students in these three areas coincided with the remote conduct of training sessions, starting from the period of the Covid-19 pandemic, in order to ensure high-quality and meaningful training sessions for students during the pandemic, the team of the faculty of the Bukhara State Medical Institute conducted all its classes using the open Moodle platform.

During this period, the teaching staff of the Department of Biophysics and Information Technologies,including me, created their own electronic course, in which I taught information technologies in education and information technologies in medicine in their groups in three languages: Uzbek, Russian and English, for the purpose of using students and conducting remote training sessions.

In order to find out how well the students mastered the subject areas between the second and first courses of study, using the tests section of the Moodle program, tests were obtained, including test questions on the topics.

I have analyzed and studied the results of this test, and also received the results of the test analysis below.

This article presents the results of two surveys aimed at reflecting the experience of students and teachers working with Moodle, mainly on these issues, and, consequently, the impact of using this LMS in everyday teaching practice on students' academic achievements. The study was conducted as part of a bilateral project between our institutes. Participation in the study was voluntary and anonymous for both students and teachers.

The results of our research should be of interest to university administrators, teachers and students who plan to offer, teach or take courses implemented in Moodle. In addition, it can help many universities that are still deciding how widely they offer online or mixed courses and which are the most suitable platforms they use to structure their offers that are used in the research conducted. A discussion of the results from the point of view of both students and teachers is presented to promote future research and innovation in the practice of online learning.

Integration of the Open Source Course Management System (Moodle) into the teaching of the course At the Bukhara State Medical Institute, first-year students enrolled in the MBBS program were given training sessions on information technologies in medicine using the Moodle electronic platform as an additional electronic base when passing a traditional lesson. Medical universities around the world are currently experimenting with innovative ways to use web-based learning in addition to the existing teaching and learning process. Recently, we used a popular open source course management system (LMS) called a modular Object-oriented Dynamic Learning Environment (Moodle). 
The Institute has created an online electronic course this course (Moodle.bsmi.uz) is called our international students who were accepted based on our MBBS full-time program in Information Technology in Medicine. The integration of the Moodle website into our education was evaluated by the online activity magazine, student exam results and student reviews. The Moodle platform was easy to use, helped deliver course materials efficiently, and had collaboration features to learn the work in which students sent their answers to questions and assignments home during the school year as files through a section called "send assignments" posted on the "practical classes" page hosted on the Moodle platform, and spoke positively about classroom activities that they could use as additional information to complete. In addition, it was found that the participation of students and the results of online quizzes, as well as the results of their final exams, were successful. We recommend Moodle as a useful tool for teachers who are interested in integrating web-based learning into an existing curriculum. e-learning; blended learning; virtual learning environment; web-based learning.

With the advent of a new era of information technologies, web-based learning is becoming an important component of the modern educational process in higher educational institutions. Many higher education institutions have adopted LMS Moodle course management systems; also called Virtual learning environments to facilitate online learning. LMS Moodle consists of software packages that allow teachers to create online learning sites for downloading meaningful materials, facilitating communication between students and teachers through discussion forums, email and chat functions, creating online quizzes and questionnaires, as well as managing several student groups. These functions can help teachers organize their work. course materials, effectively distribute training materials and implement creative teaching methods. LMS Moodle can also be used to implement the current course assessment, facilitating the joint development of educational materials and improving the quality of student learning. This LMS platform is easy to use, easily accessible, stable, flexible and able to integrate with other platforms.

The most widely used open source LMS in an educational environment is a modular object-oriented dynamic learning environment (Moodle). Moodle was created by Martin Dugiamas (Curtin University of Technology, Perth, WA, Australia) [9].

Moodle (it stands for Modular Object-Oriented Dynamic Learning Environment) - free e-learning system. This is an open web application, on the basis of which you can create a specialized platform for the development of training of students or employees [1,9].

Through the Moodle e-learning system, you can train and test students from all over the world from a distance. Plugins play an important role in the platform - modules that help to change the design and expand the functionality of the system. Plugins are developed by members of the Moodle community, and for the most part they are available for free. Now there are more than 1500 plugins in use. [1,34]

Today, Moodle is one of the most popular e-learning platforms. It has been translated into more than 100 languages, and it is used by major universities around the world.

\section{MATERIALS AND METHODS}

The Bachelor of Medicine (MBBS) program offered at the Bukhara State Medical Institute is designed for 6 years, and the admission of students is based on the individual ability and intelligence of students. Information technology in medicine is one of the compulsory subjects offered in the first year, and is traditionally taught through lectures, 
classroom training and practical classes, all of which involve personal communication with students. During the entire academic session 2020-2021, we supplemented the existing training modes with an online Moodle website called moodle, bsmi.uz. We were the first department in the faculty to introduce the Moodle platform for this group of MBBS students.

At the beginning of the 1st semester, all first-year students of MBBS 55 were asked to register on the website themselves moodle.bsmi.uz, using individual usernames and email addresses. During the introductory week, we were given a brief briefing on moodle.bsmi.uz. Along with a set of registration instructions, students were also provided with a registration key that acted as an access code to the site. When the registration key was first entered, students were automatically assigned to 5 separate groups based on their study group assigned by the teacher. Enrollment in moodle.bsmi.uz it was available from the beginning of the 1 st semester to the end of the 2 nd semester.

Exam results. The first year of our MBBS course in Information Technology in Medicine consisted of the main exams: one exam at the end of the semester. All students had to pass these exams and get a pass to move on to the second semester. These exams consist of questions on the main topics. For the purposes of this study, the evaluation of the components of information technology in medicine on exams obtained from moodle.bsmi.uz during the semester, respectively. At the end of the semester, we conducted a final test on Moodle, the average result of mastering the material by students according to the results of this test was $79 \%$.

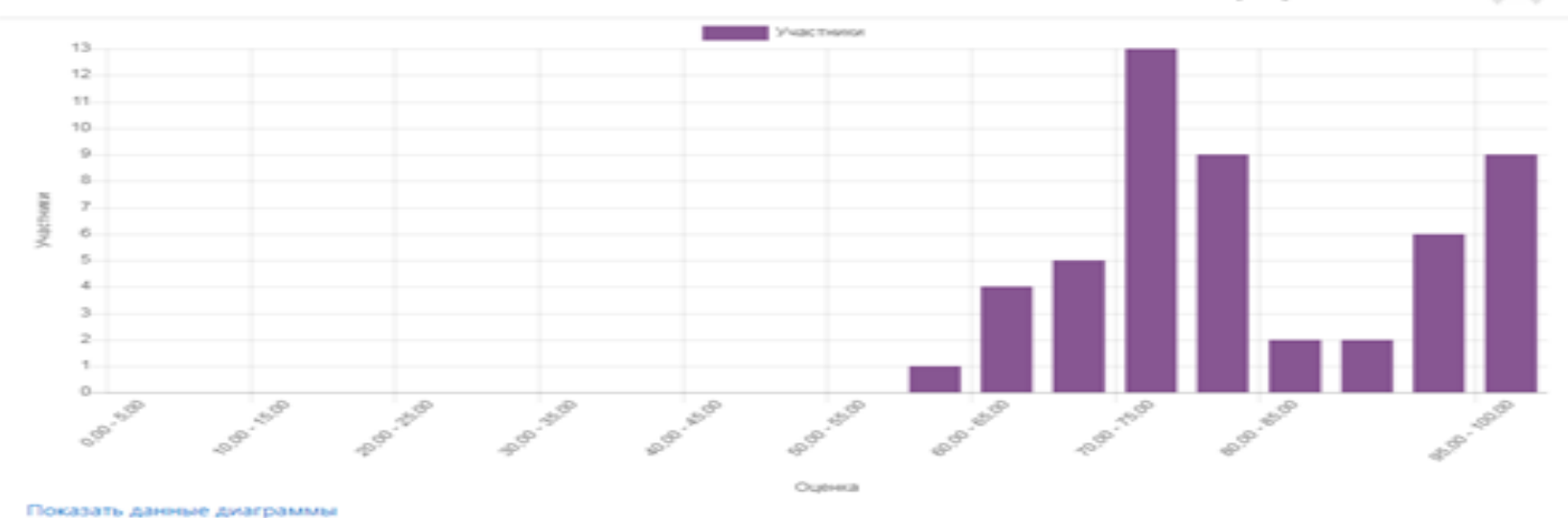

\section{RESULTS}

Study participants

All 100\% (55) first-year MBBS students have registered as users moodle.bsmi.uz. These users were equipped with sufficient information technology knowledge to use the LMS thanks to their information technology training at the institute. The classrooms, library, computer laboratory and student dormitories had a sufficient number of computers, as well as cell phones, tablets, so that students could access moodle.bsmi/uz. A total of 55 students answered the questionnaire: In the student survey, $81.8 \%$ of students chose the Moodle platform, of which $7.2 \%$ of students chose Zoom, and the remaining $10.9 \%$ of students chose Telegram Messenger. 


\section{Which of the programs that you \\ used for distance learning was convenient for you}

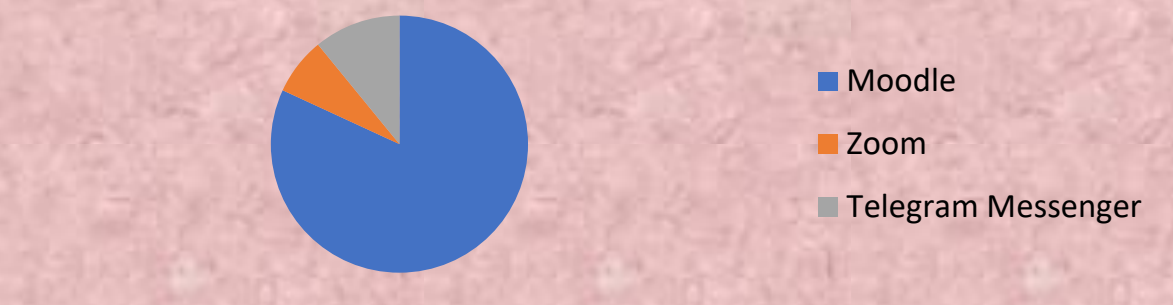

\section{CONCLUSIONS}

Based on our initial assessment, the integration of the freely available Moodle platform into our training in Information Technology in Medicine in the first year of MBBS clearly provided many advantages. The Moodle platform was user-friendly, had many interactive features that could improve the learning experience of students and provide greater flexibility in learning. The introduction of Moodle has also improved the performance of students in the final final exams, which indicates a positive impact on the results of students' learning. We recommend Moodle as an option for Information Technology teachers who are interested in including LMS Moodle in their educational activities.

\section{REFERENCES:}

1. Asadova Yu. Using the moodle platform to organize training during the covid-19 pandemic / Education and innovative research №1. http://www.interscience.uz 2021 PP. 44-54. (In English)

2. Asadova Yu. I using the Moodle Platform in Extreme Cases. Centralasian journal of mathematical theory and computer sciences Volume: 02 Issue: 06 | Jun 2021 - PP. 13-19. ISSN: 2660-5309 http://cajmtcs.centralasianstudies.org/index.php/CAJMTCS (In English).

3. Asadova Yu.I. International journal on human computing studies. Passing the Traditional Lesson with the Help of Open Moodle Platforms. https://journals. researchparks.org/index.php/IJHCS e-ISSN: 2615-8159 | p-ISSN: 2615-1898. Volume: 03 Issue: 5 | Jul 2021. - PP. 1-8.

4. Asadova Yu.I. Electronic educational platform-the basis of students' project activity / II International Online scientific and practical conference "topical issues of pharmacology: from pharmacology development to their rational use" collection of abstracts May 6-7, 2021 - PP. 138-141. (In Russian.).

5. Asadova Yu.I. MOODLE platform - as a basis for organizing during a pandemic covid-19/ II International Online scientific and practical conference "topical issues of pharmacology: from pharmacology development to their rational use" collection of abstracts May 6.7.2021. - PP. 175-176. (In English).

6. Asadova. Yu.I. [Using the MOODLE platform to organize training during the Covid19 pandemic]. [International scientific and practical conference "modern problems of applied mathematics and information technologies". Bukhara. SU. 2021. - P3. 482-485. (In English). 
7. Asadova Yu.I.The use of the moodle platform in the traditional training of foreign students accepted under the MBBS program, the subject of information technologies in medicine [International scientific and practical conference "modern problems of applied mathematics and information technologies". Bukhara. SU. 2021. - PP. 485-487. (In Russian.)

8. Ahmed 0. (2005). Migrating from Proprietary toOpen Source Learning Content ManagementSystems, Department of Systems and Computer Engineering, Carleton University, Ottawa.

9. Al-Ajlan A., \& Zedan H. (2008). Why Moodle, In L. O‘Conner (Ed.), The 12th IEEE International.

10. Budimac Z., Putnik Z., Ivanović M., Bothe K., \& Schützler K. (2011). On the Assessment and Self-Assessment in a Students Teamwork Based Courseon Software Engineering. Computer Applications inEngineering Education, 19 (1). - PP. 1-9.

11. Dantas A.M., Kemm R.E. A blended approach to active learning in a physiology laboratory-based subject facilitated by an e-learning component. Adv Physiol Educ 32. 2008. - PP. 65-75.

12. Dougiamas M., Taylor P. Moodle: using learning communities to create an open source course management system. In: World Conference on Educational Multimedia, Hypermedia and Telecommunications 2003, edited by Lassner D, McNaught C. Honolulu, HI: Assoc. for the Advancement of Computing in Education, 2003. - PP. 171-178.

13. Кравченко Г.В., Волженина Н.В. Работа в системе Moodle: руководство пользователя: учебное пособие. - Барнаул, 2012.

14. M.F. Atoyeva, R. Safarova. Pedagogical integration as a means of forming professionally important qualities among students of a medical university. Academicia. ISSN: 2249-7137 Vol. 10, Issue 8, August 2020. Impact Factor: SJIF $2020=7.13$ ACADEMICIA: An International Multidisciplinary Research Journal https://saarj.com.

15. M.F. Atoyeva. Pedagogical Tests As An Element Of Types Of Pedagogical Technologies. The American Journal of Applied Sciences, 2(09), (TAJAS) SJIF-5.276 DOI10.37547/tajas Volume 2 Issue 9, 19.09.2020. ISSN 2689-09. 92 The USA Journals, USA www.usajournalshub.com/index.php/tajas 164-169. Имп.5.2.

16. Farkhodovna A.M. (2020). The problems of preparing students for the use of school physical experiment in the context of specialized education at secondary schools. European Journal of Research and Reflection in Educational Sciences, 8 (9). - PP. 164-167.

17. Saidov S.O., Fayzieva Kh.A., Yuldosheva N.B., Atoyeva M.F. The Elements Of Organization Of The Educational Process On The Basis Of New Pedagogical Technologies. The American Journal of Applied Sciences, 2(09), (TAJAS) SJIF-5.276 DOI-10.37547/tajas Volume 2 Issue 9, 19.09.2020. ISSN 2689-09.92 The USA Journals, USA www.usajournalshub.com/ index.php/tajas 164-169. Имп.5.2.

18. Atoeva Mehriniso Farhodovna, Arabov Jasur Olimboevich, Kobilov Bakhtiyor Badriddinovich. (2020). Innovative Pedogogical Technologies For Training The Course Of Physics. The American Journal of Interdisciplinary Innovations and Research, 2(12). PP. 82-91.

19. Н.П. Клейносова, Э.А. Кадырова, И.А. Телков, О.М. Баскакова, Р.В. Хруничев. Дистанционное обучение в среде Moodle: методические указания. Рязань. - 2011.

20. Kakasevski G., Mihajlov M., Arsenovski S., \& Chungurski, S. (2008). Evaluating Usability inLearning Management System Moodle. In V. Luzar-Stiffler V. Hljuz Dobric Z. Bekic (Eds.), The 30thInternational Conference on Information. Informatica 37 (2013) 221-230 Technology Interfaces (ITI 2008), (PP. 613-618). Los Alamitos: IEEE Press. 
21. Инновационные методы обучения в высшей школе. Инновационные методы обучения в высшей школе. Выпуск 2015 (Сборник статей по итогам методической конференции ННГУ 12-13 февраля 2015 г.). - Нижний Новгород: ННГУ им. Н.И. Лобачевского, 2015. - С. 151.

22. Literature Review on the Impact of Digital Technology on Learning and Teaching ICF Consulting Services Ltd November 2015.

23. M.F. Atoyeva. The significance of periodicity at teaching physics. The Way of Science. - Volgograd, 2016. - № 10 (32). - PР. 62-64.

24. Атоева М.Ф. Эффективность обучения электродинамике на основе технологии периодичности. The Way of Science. - Volgograd, 2016. - № 10 (32). PР. 65-66.

25. BARRON'S *AP and Advanced Placement Program are registered trademarks of the College Board, which was not involved in the production of, and does not endorse, this book. 7TH EDITION Roselyn Teukolsky, M.S. Innovative Methods of Teaching Dr. Damodharan V.S. ACCA, AICWA and Mr. Rengarajan. V AICWA Strategies for effective teaching. A Supplement for Special Education Louisiana Teacher Assistance and Assessment Program Louisiana Department of Education Cecil J. Picard State Superintendent of Education 2004.

26. Атоева М.Ф. Периодичность обучения физике. Аспирант и соискатель. Москва, 2010. - №6. - С. 41-43.

27. M.F. Atoyeva. Interdisciplinary relations in physics course at specialized secondary education. The Way of Science. - Volgograd, 2016. - № 9 (31). - PP. 22-24.

28. International Journal of Research in Education and Science (IJRES)Teaching and Learning with Technology: Effectiveness of ICT Integration in Schools Simin Ghavifekr, Wan Athirah Wan Rosdy Faculty of Education, University of Malaya, Malaysia, drsimin@um.edu.my Volume 1, Issue 2, Summer 2015.

29. Лаврентьев Г.В. Дистанционное обучение: теоретико-методологические основы // Вестник Алтайской академии экономики и права. - 2012. - Вып. 2 (25).

30. M.F. Atoyeva. Use of Periodicity in Teaching Physics. Eastern European Scientific Journal. - Düsseldorf-Germany, 2017. № 4. - PP. 35-39.

31. M.F. Atoyeva. Didactic foundations of inter-media relations in the training of university students. International Scientific Journal. Theoretical \& Applied Science. p-ISSN: 2308-4944 (print) e-ISSN: 2409-0085 (online). Year: 2020 Issue: 06 Volume: 86. - P. 124.

32. The learning platform in distance higher education: student's perceptions. Turkish Online Journal of Distance Education-TOJDE January 2019 ISSN 1302-6488 Volume: 20 Number: 1 Article 5. 